\title{
Anthropic pressure and management of the municipal natural area of the "Clot de Galvany" (Elche, Spain)
}

\author{
M. Vera González ${ }^{1}$, J. Navarro Pedreño ${ }^{1}$, J. C. Aranda López ${ }^{2}$ \\ \& I. Gómez Lucas ${ }^{1}$ \\ ${ }^{1}$ Department of Agrochemistry and Environment, \\ Miguel Hernández University of Elche, Spain \\ ${ }^{2}$ Department of Environment, Elche City Hall, Spain
}

\begin{abstract}
The Municipal Natural Park (MNP) of the "Clot de Galvany" is situated in the municipality of Elche (Alicante, South-East of Spain). It includes lagoons, small hills and its coastal area (beaches and sand dunes) and it has important wildlife (flora and fauna), geology and paleontology, soils and landscape diversity, and relevant socio-cultural values (old military ruins and a roman settlement among others). This MNP is included in the European Natura 2000 Network inside the Site of Community Importance (SCI) of Tabarca (ES5213024). However, in recent decades, it has undergone strong anthropic pressure. This work describes the analysis of the conditions and the pressure exerted by man in this Municipal Natural Area, such as habitat fragmentation, increase of visitors, loss of biodiversity by the introduction of invasive species, damage to the infrastructure, etc. The Department of Environmental Control and Educational Service of this protected area obtained the data used in this work, from monthly and annual reports through the management of this natural park for the period 1998-2013. These data have been incorporated into a Geographic Information System and been analyzed. The results indicated that it is so clear that habitat fragmentation has been due to the different owners of the land (public or private) and urban pressure. The pressure from visitors is most important in spring and summer (especially in the coastal area), and it is notorious for the presence of invasive species due to the abandoning of animals that were previously pets. However, several actions like the increment of the attendance of the visitors, the creation of new infrastructures to preserve some areas and the programs to capture and take
\end{abstract}


away the invasive species are positive for the natural park. These measures improve the management of the Municipal Natural Area and the protection of the wildlife and landscape.

Keywords: human pressure, invasive exotic species, GIS Management, Natura 2000 Network.

\section{Introduction}

Natural areas have suffered the pressure from historical man in order to obtain resources, economic and social use (agriculture and tourist, industrial or recreational activities), and the development of urban areas. This situation has resulted in a loss of quality and the original characteristics of the natural areas [1] and it is necessary to establish strategies to preserve them.

The overall aim of this study is to contribute to improve the management of the Municipal Natural Park (MNP) of "Clot de Galvany" through knowledge, analysis and assessment of the main elements of anthropogenic origin that have caused alterations in the MNP.

The specific objectives of this study are: a) to analyze the relevant conditions related to anthropogenic land use; b) the habitat fragmentation and damage to infrastructure; c) the anthropic conditions associated with loss of biodiversity; d) the impact of the introduction of invasive species; e) identify the areas where damage is presented within the geographical context through the use of a Geographic Information System (GIS); and f) to propose measures to improve the management of MNP.

\section{Methodology}

\subsection{Description of the area}

The study area is one of the most relevant natural areas of the province of Alicante composed by a set of amphibious zones. The "Clot de Galvany" is basically a Municipal Natural Park (MNP) with a protected surface of 366.31 ha and located between the rural areas of "El Altet" and "Los Balsares", and the seacoast of the municipality of Elche $\left(38^{\circ} 14^{\prime} 52^{\prime \prime} \mathrm{N} 0^{\circ} 32^{\prime} 16^{\prime \prime} \mathrm{W}\right)$. According to the biogeography of the area, this should include part of the municipality of Santa Pola, area of "Torre Brissó", although it is not under protection [2]. The area is under the protection of the law figure of Municipal Natural Park (MNP), and is part of an Important Bird and Biodiversity Area (IBA) and European Site of Community Importance SCI (ES5213024).

The floristic list made by the Department of Control and Environmental Education of the "Clot de Galvany" (DCEE) since 1998 and updated in 2013, lists 476 species, 107 different botanical families (including algae, fungi and flowering plants) [3]. The flora is distributed among all the low hills, abandoned cultivation fields, salt marshes and several ponds composing the set of wetlands of "Balsares-Clot de Galvany", and coastal dunes of "l'Altet-ArenalsCarabassi". Note that some botanical species as the Lavender (Thymus 
moroderi) and Evergreen (Limonium santapolense) are included in the Valencian Catalog of Endangered Species of Flora published in Decree 70/2009 [4] and in the Red List of Spanish Vascular Flora [5] following the criteria of the International Union for Conservation of Nature (IUCN).

The annual presence of waterfowl and wading birds in ponds is mainly conditioned by the evolution of water levels in each pond throughout the seasons. This depends on the rate of annual rainfall and the artificially water supply with treated water from the Wastewater Treatment Plant (WWTP) of "Arenales del Sol". 133 bird species, belonging to 42 different families were recorded in 2013 [3]. It should be mentioned the presence of the Marbled Teal (Marmaronetta angustirostris), and the presence and reproduction of the Whiteheaded Duck (Oxyura leucocephala), both species cataloged as endangered by the Spanish Catalogue of Endangered Species [6] and Valencian Catalog of Endangered Species of Fauna [7]. Annual surveys are conducted to monitor their status.

Other vertebrate faunal groups are presented: 48 species identified in the MNP, with 2 species of amphibians, 19 reptiles and 26 mammals including 3 species of cetaceans [3].

The DCEE [3] has been making annual and monthly reports based in actions programs since 1998. The memories (1998-2013) showed the results of the four main Management Programs established to MNP Clot de Galvany. These are Control and Monitoring Program (dedicated to check the fauna and flora), Environmental Education Program (educational resources and attendance to visitors), Inspection Program (area surveillance) and Control of Quality Program (environmental quality).

The Habitat fragmentation was studied by using aerial photographs that analyze two historical moments, before and after the current urban development (American Flight 1956-57 and current picture of the year 2012 PNOA/National Geographic Institute IGN-ICV (C) were reviewed.

The number of visitors was obtained by consulting and analyzing the Census of Visitors (CAV) and vehicle annual reports from 2003-2013.

The Inspection Programs recorded the anthropic incidents inside the MNP. The incidents considered for this work where those that accumulated a larger number of incidents per year (greater than or equal to 25 in 2013) and were more related to anthropogenic land use. These nine incidents were sports, aggression due to the tied pets, pets loose, cyclists in the environmental educational walking paths (EEWP), cyclists outside the EEWP (free raid), damage to infrastructure, people outside the EEWP and vehicles within the site.

The presence of invasive exotic species (IES) was obtained from the data provided by the reports and management reports of the MNP and the Trachemys LIFE Project [8]. Invasive exotic flora and fauna were identified in the MNP, their presence, and the measures to combat were evaluated and related to the visitors and their distribution was mapped using a Geographic Information System (GIS). 
The software used in this study were QGIS v2.0.1 and Office 2013 (C), Map Database from the "Instituto Cartográfico Valenciano" (ICV) and "Instituto Geográfico Nacional de España” (IGN).

\section{Results and discussion}

\subsection{Habitat fragmentation}

The comparison of aerial images of 1956-57 (fig. 1) and 2012 (fig. 2) shows a clear urbanization of the coast. The sand dunes "l'Altet-Arenals-Carabassi" was perfectly preserved in 1956 (typical coastal sand dunes) while nowadays the urbanization of "Arenales del Sol" fragmented this habitat, creating a barrier in the coast.

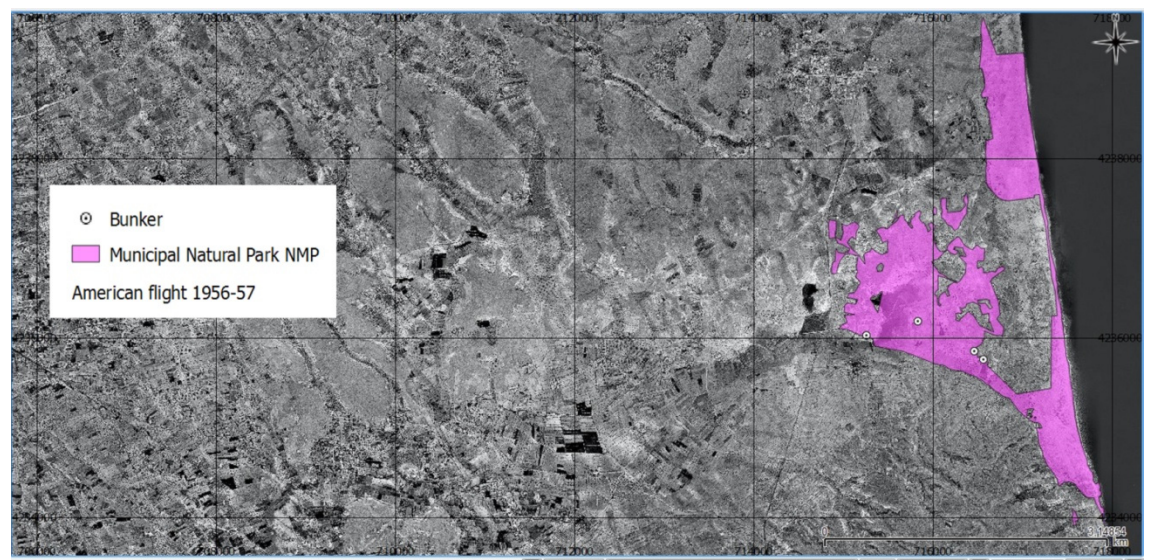

Figure 1: American flight 1956-1957. MNP is delineated in rose colour.

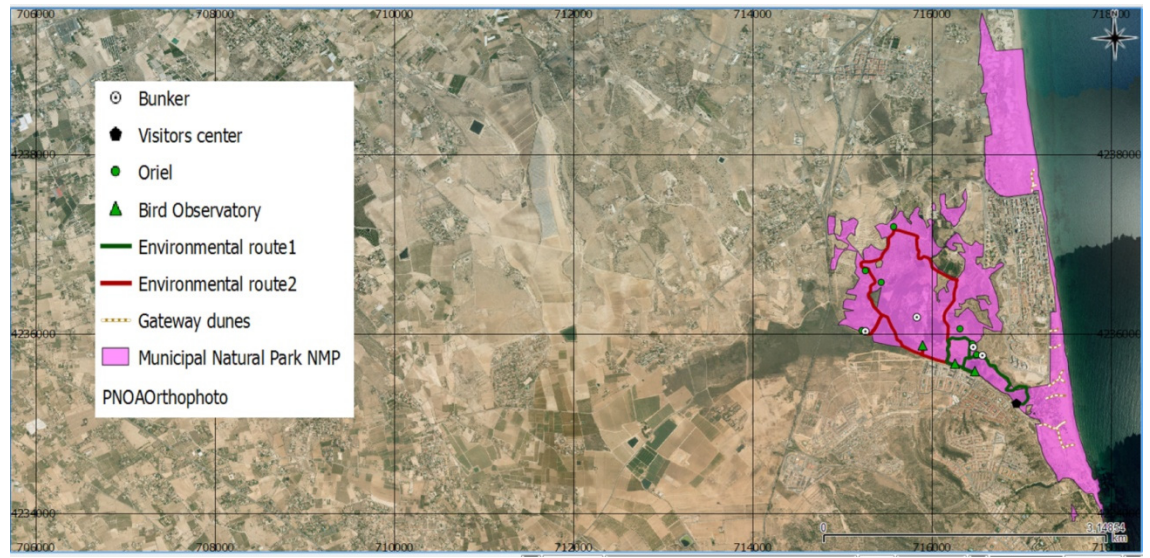

Figure 2: $\quad$ Situation in the aerial image of 2012 of the MNP (PNOA/IGN). 
Fig. 3 shows a map with the perimeters of each of the forms of protection affecting the area of study (Municipal Natural Park NMP, Important Bird and Biodiversity Area (IBA) and Site of Community Importance SCI). IBA and SCI are coincident but exclude in part the MNP. There are areas of high natural and landscape quality, which are outside of the protection figure MNP, most being privately owned, but are included in the IBA and SCI, as the case of the area of "Balsares" (yellow colour) which also is a wetland area. Aranda López and Lacarte Monreal [9] indicate that a Special Protection Plan to improve the protection is being prepared.

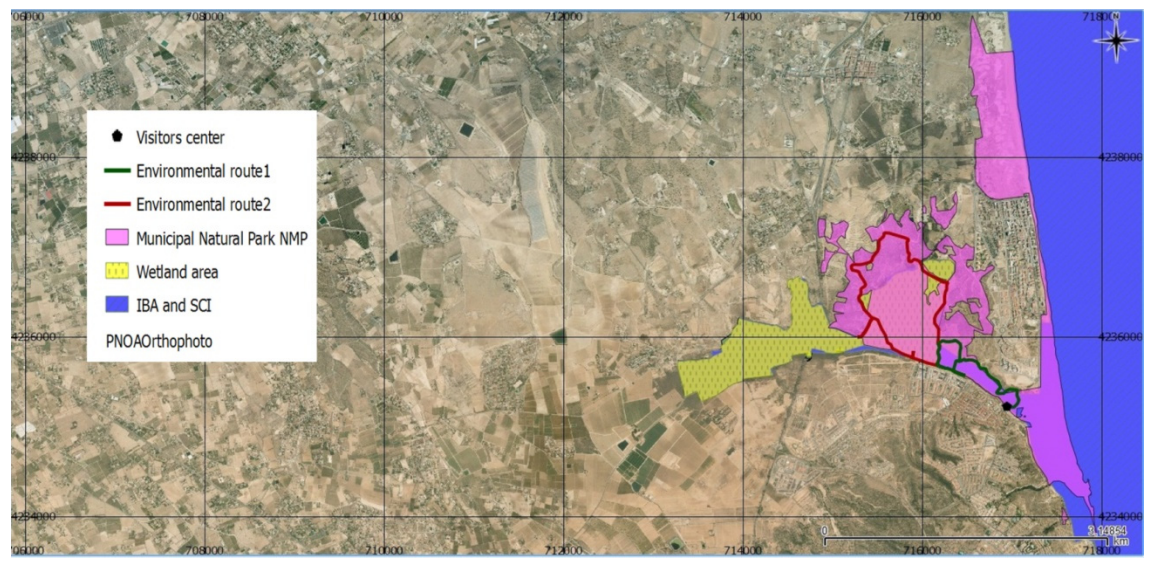

Figure 3: Habitat fragmentation and protection figures recognized in the area.

\subsection{Number of visitors}

The amount of visitors between 2003 and 2013 were analyzed in 3 selected zones (representing three different habitats): Beach of "Carabassi" (Beach), "Clot" wetland (Clot) and recreational area (pine forest, RA), following the guidelines of other reports such as Europarc-Spain [10].

The annual results of these three areas, the sum of all of them called "total census of visitors" and the annual value of visitors attended by DCEE (Total visitors attended) are represented in fig. 4.

The total number of visitors estimated for the MNP was calculated by summing the last two values (visitors estimated). The annual admissions has an average of 18019 visitors/year and 1509 visitors/month. The number of vehicles has an average of 4739 vehicles/year. There was a decrease of visitors (20032006), close to 8093 visitors, while it was increased from 2007 (over 20000 visitors/year). The same trend was observed for vehicles (Clot and Beach). The temporary closure of the visitor's center between 2011 and 2012 could have an impact on the reduction observed in 2013. Therefore, the DCEE is expanding the promotion activities as a strategy to increase the visitors. The tourist pressure is not homogeneous in the 3 areas studied, putting further pressure on the Beach of 


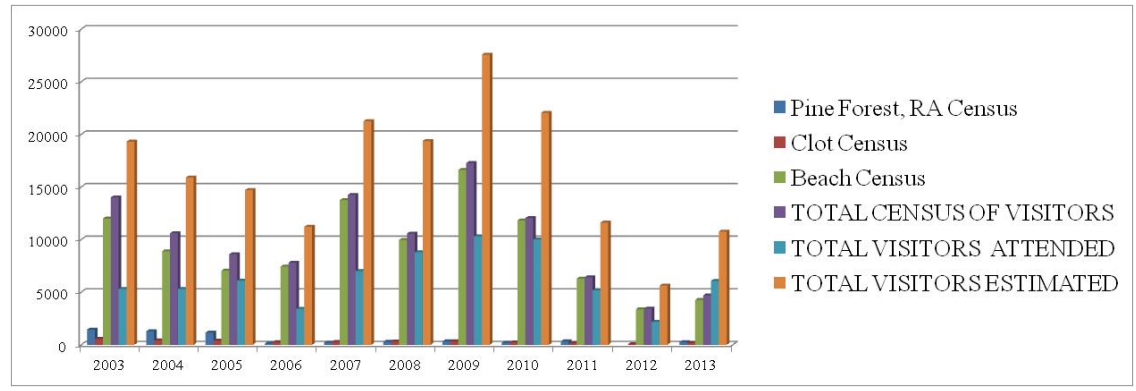

Figure 4: Amount of visitors from 2003 to 2013.

"Carabassi", which concentrates visitors in the summer months, from June to August.

Visitors can walk inside the MNP (fig. 5) or being attended by the DCEE. Analyzing number of visitors in 4 specific years (2003, 2006, 2009 and 2013), an increment on the percentage of visitors who were attended by DCEE was observed, $27 \%$ in 2003, 33\% in 2006, 38\% in 2009 and reaching 56\% in 2013. Visitors are mostly attended by the team of DCEE in recent years which discloses the values of the environment and this is a positive effect.

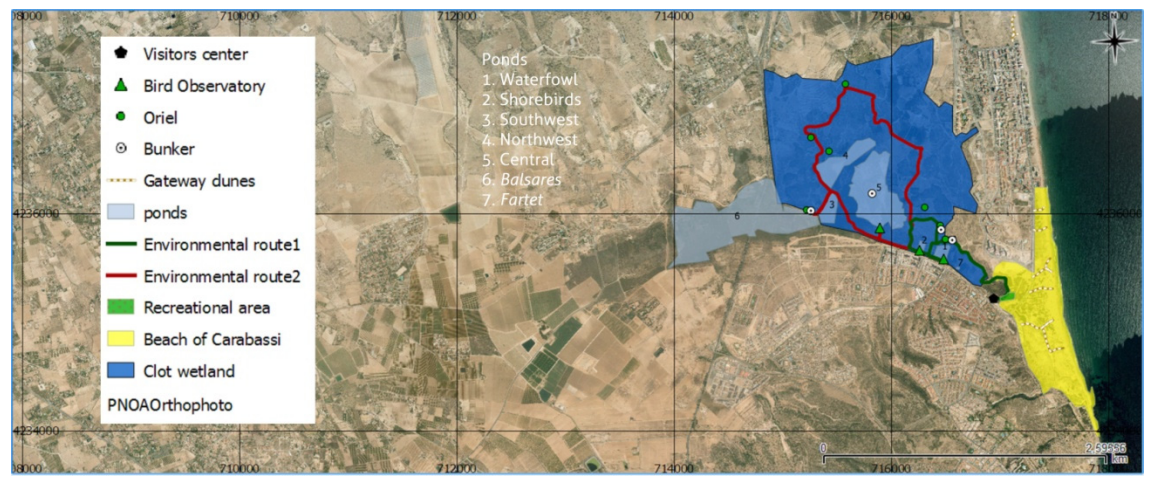

Figure 5: Environmental pathways (EEWP) in the different habitats: beach and sand dunes, wetlands and shrub and pine areas.

\subsection{Anthropic incidents}

Fig. 6 shows the number of monthly incidents for the period 2003-2013. The annual average is 1765 incidents/year, and the values have a random distribution. There is a maximum in 2005, due to a high value in spring, with 1508 incidents in March, 824 in April and 599 in May, mostly due to the presence of visitors outside the EEWP. Monthly mean is of 147.04 and a standard deviation of 176.13 for the period 2003-2013 and therefore global values have a random distribution, but it is noteworthy that the trend line indicates a slight decrease of number of incidents/month over time. The trend of incidents per season determines that they are concentrated mainly in spring and summer. 


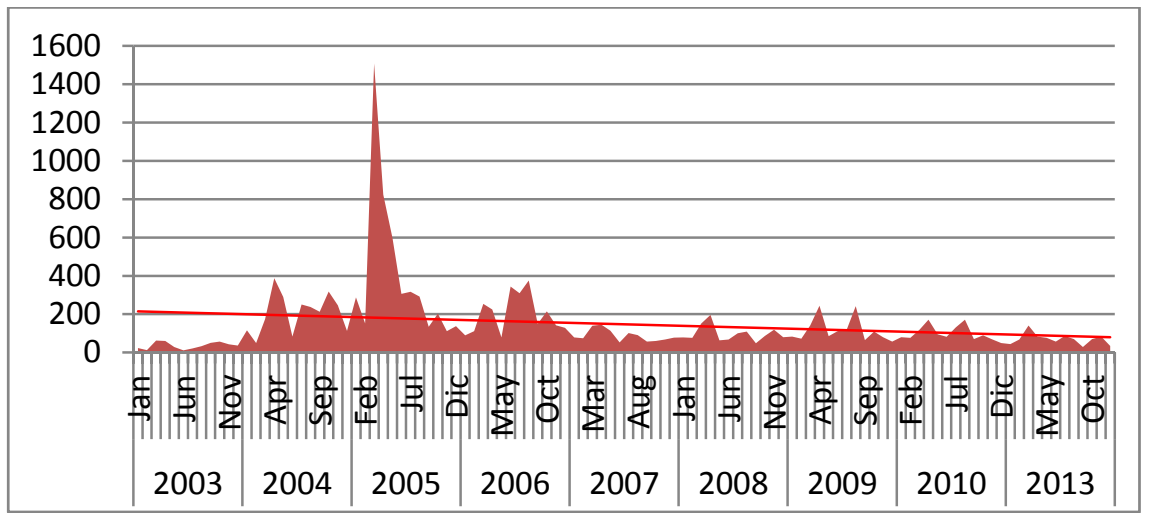

Figure 6: Monthly volume of occurrence in the period 2003-2013.

It is interesting to analyze the evolution of the number of incidents in accordance with the number of visitors to the MNP. Fig. 7 shows the graphical result, with a slight upward trend line representing a higher volume of incidents produced in accordance with the number of visitors to the MNP. Higher number of visitors is associated to a higher volume of incidents recorded.

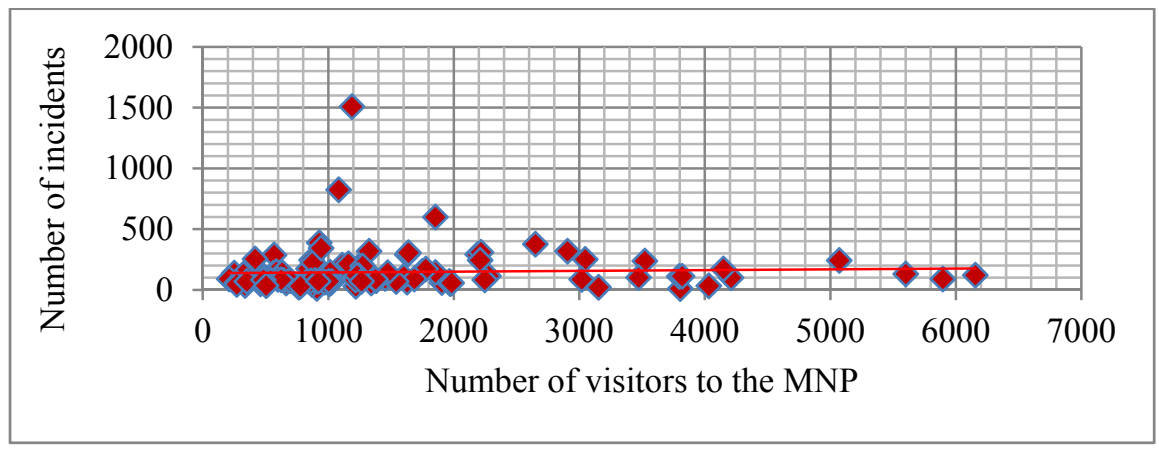

Figure 7: Incidents versus number of visitors.

Analyzing the overall percentage of incidents, we found that the most important was "cyclists in the EEWP (31\%)" followed by "people outside the paths (24\%)". After them: "domestic animals (13\%)", "environmental disturbance and damage (11\%)" and "damage to infrastructure (8\%)", "tied Pets (5\%)", "cyclists outside the EEWP (4\%)" and "sports activities (4\%)". All of them affected the wildlife, soils (erosion and loss of quality) and landscape of the protected area. To control and management these incidents, the pathways were clearly delineated and marked along years, wood bridges built over the sand dunes in 2009 and a surrounding ornithological fence in 2008. 


\subsection{Invasive exotic species (IES)}

A total of 39 species Invasive Exotic Plants have been identified since 1998. The presence may be associated to abandoned crops, gardening or spontaneous appearance [3]. These species account for $8.19 \%$ of total biodiversity of flora identified in the MNP. Several strategies are adopted to combat and control the IES depending on the habitat considered. The presence of Caulerpa racemosa (Caulerpa) in the coastal area is a major threat to seagrass meadows. A study monitoring and controling Caulerpa racemosa on the beach "Carabassi" is carried out since 2004 (between the city of Elche and the University of Alicante [11]). The presence of Carpobrotus sp (Pigface), Arundo donax (Giant cane) and Penissetum setaceum (Fountaingrasse) is controlled in sand dune ecosystems by volunteers and the DCEE yearly, as well as for the Agave americana (American aloe) and Opuntia subulata (Erect prickly pear) presented in roadsides, pathways and Mediterranean maquis ecosystem. Mapping of invasive exotic plant species by the DCEE is being done since April 2013.

Table 1: $\quad$ List of IES vertebrate fauna observed.

\begin{tabular}{|c|c|l|l|c|c|}
\hline ID & Class & \multicolumn{1}{|c|}{$\begin{array}{c}\text { IES } \\
\text { Scientific name }\end{array}$} & $\begin{array}{c}\text { IES } \\
\text { Common name }\end{array}$ & $\begin{array}{c}\text { 1st year } \\
\text { observed }\end{array}$ & $\begin{array}{c}\text { Total } \\
\text { Obs. }\end{array}$ \\
\hline 1 & Reptiles & Iguana iguana & Green iguana & 2006 & 2 \\
\hline 2 & Reptiles & Chamaeleo calyptratus & Veiled chameleon & 2010 & 1 \\
\hline 3 & Reptiles & Trachemys sp. & Red-eared slider & 2001 & 530 \\
\hline 4 & Reptiles & $\begin{array}{l}\text { Graptemys } \\
\text { pseudogeographica }\end{array}$ & False map turtle & 2006 & 3 \\
\hline 5 & Birds & Cygnus olor & Mute swan & 2004 & 1 \\
\hline 6 & Birds & Cygnus atratus & Black swam & 2010 & 1 \\
\hline 7 & Birds & Poicephalus senegalus & Senegal parrot & 2003 & 1 \\
\hline 8 & Birds & Psittacula krameri & $\begin{array}{l}\text { Rose-ringed } \\
\text { parakeet }\end{array}$ & 2004 & 1 \\
\hline 9 & Birds & Myiopsitta monachus & Monk parakeet & 2004 & 3 \\
\hline 10 & Mammal & Tamias sibiricus & Siberian chipmunk & 2007 & 3 \\
\hline 11 & Mammal & Felis catus & Domestic cat & 1999 & 343 \\
\hline
\end{tabular}

The existence of IES fauna involves various problems of competition, displacement and predation of native species. This is added to the strong anthropic pressure that exists on this spot of biodiversity; even more it determines a problematic survival of wildlife. The annual management reports from 1998 to 2013 [3] registered 11 species of IES fauna in the MNP, accounting for $6 \%$ of total biodiversity of vertebrate fauna. Table 1 shows the list of invasive vertebrate fauna cataloged as invasive species by the Spanish Catalogue of Invasive Species [12,13] and Valencian Catalog of Invasive Species [14] and includes another specie, Felis catus, such an invasive species, identified within the MNP and the total number of observations. It can be concluded that $98.2 \%$ of 
the observations were associated to 2 species, Trachemys sp and Felis catus (59.62\% and $38.58 \%$, respectively).

In fact, the domestic cat (Felis catus) is the most damaging specie in terms of disease to native wildlife carnivorous mammal and can be a serious problem for reproduction and survival of wildlife. Upward trend of its population related to urban growth in the vicinity is observed. Control measures as trapping have been development in the MNP [3] but little positive results have been obtained. The total citations of invasive fauna in these 16 years (1998-2013) are 889. An increase in the number of observations was appreciated until 2006, the year with a maximum value of 165 , and thereafter, a gradual decline is appreciated. This final decline may be due to many causes, but the management of the species like Trachemys sp should be given a special consideration: in 2006 there were 108 observations of Trachemys sp., in 2008 were 113 and from 2009 began the management project of this specie.

The MNP Clot de Galvany is one of the natural areas where the LIFETrachemys project is supporting the work of the Brigade of Biodiversity BBA2 of the DITE [8] together with the site maintenance staff. This project has conducted to control and capture of Trachemys sp. in the ponds, and it positively reduced this IES.

Fig. 8 shows the evolution in the number of observations of Trachemys sp and the number of catches of this species in 2010 (61) and 2011 (41). The LIFETrachemys project is beneficial to control this specie and prevent the loss of biodiversity in the future.

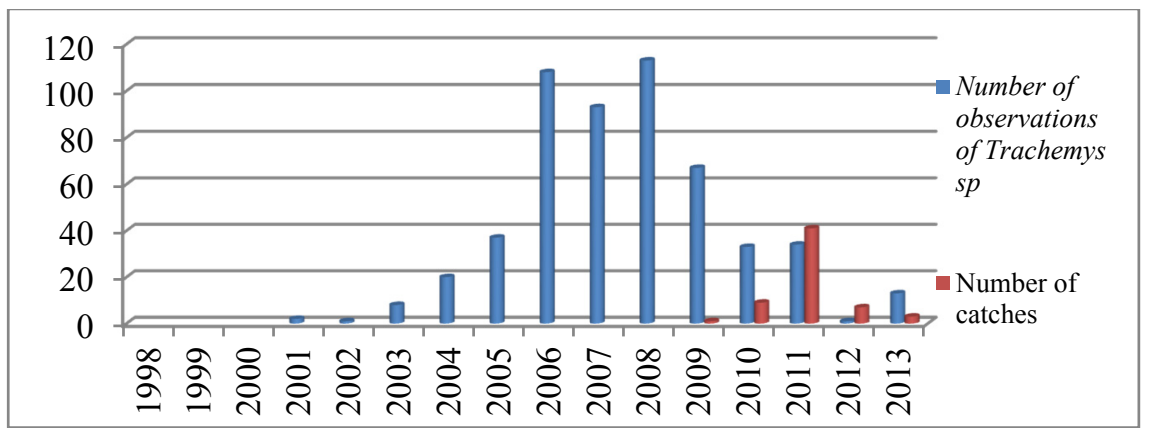

Figure 8: Comparison between observed Trachemys sp. and catches.

There seems to be some relationship between increased tourist pressures, numbers of visitors, and observing IES. The map of distribution of 11 invasive species is represented in fig. 9.

The visitor's pressure is great around the visitor's centre, recreation area and artificial ponds for waterfowl and shorebirds (close to the coastal area), places were IES of fauna were mainly detected. 


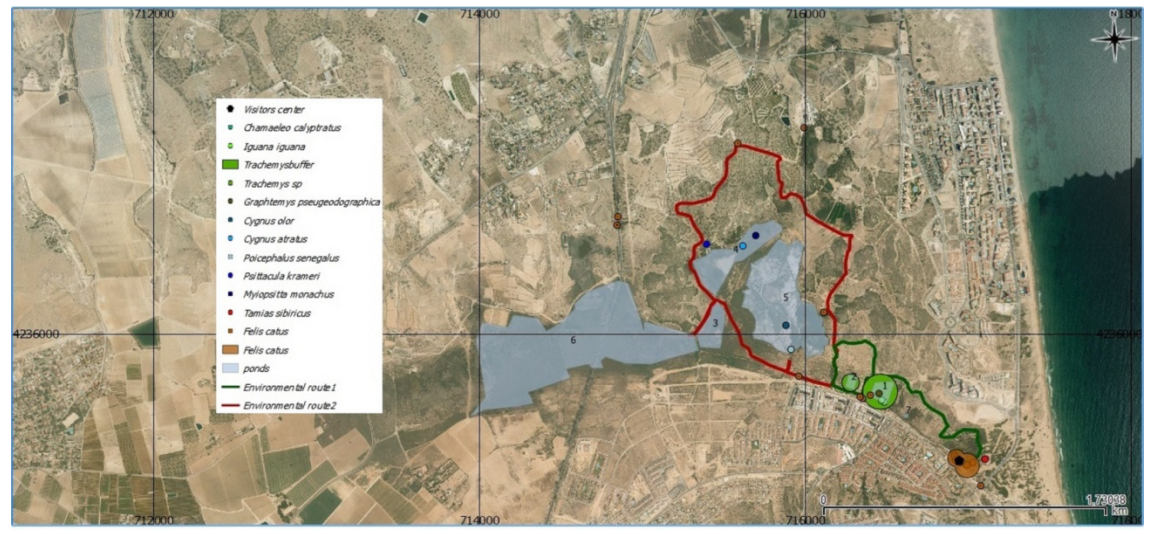

Figure 9: Presence of IES fauna.

\section{Conclusions}

The MNP "Clot de Galvany" undergoes visitors' pressure and urban occupation of nearby territory and fragmentation of the natural space and disturbs the landscape reducing its quality.

The various forms of protection (NMP, IBA, SCI) do not agree on delimiting the same space and all that hinders the integrated management of the natural environment, so this situation may be corrected.

The numbers of visitors and vehicles in the MNP has been increasing over time, affecting mainly the Beach of "Carabassi" in summer. The wetland ecosystems also suffer strong pressure. It is considered that the management measures have been successful, controlling the flux of visitors and vehicles.

The visitors attended by the team of DCEE have been increasing and as a consequence, more people are informed and aware about the values of the environment and applicable regulations. From the annual reports, it has been found that there is a relationship between number of visitors and volume of anthropic incidents detected, however incidents are decreasing. This fact suggests that the management measures undertaken are being effective and should continue and local population could be concerned by better measures and willing to contribute and being engaged to that purpose.

The problem of invasive species, flora and fauna, derived in an important management efforts, economic cost and projects associated to control them. Caulerpa racemosa and Trachemys sp. have been successfully controlled although the strategy of catches for domestic cats did not give good results. These management measures should continue, supplemented by education and environmental awareness at MNP to visitors to reduce the impact of IES.

In general, the problems detected and the management actions taken have been achieved a reduction of the negative environmental effects affecting the 
MNP and the initiatives of DCEE is a key factor. There is a considerable popular feeling favorable to the protection and improvement of this space, manifested through initiatives of non-profit entities, numerous blogs, newsletters about the Clot and others. One of the most important is the improvement of the Visitors' centre and information in the internet (http://www.clotdegalvany.es/). However, without any doubt, the best tool for improving our environment is still the education.

\section{References}

[1] García Sánchez, P. \& Romero Montero, A., Desarrollo turístico en el litoral ilicitano, University of Alicante, pp 1-70, 2011.

[2] Abela Furió, F., Jordán Vidal, M.M, García Sánchez, E., Navarro Pedreño, J., Soriano Disla, J.M., Aproximación al estudio de los fósiles que afloran superficialmente en el Clot de Galvany y su entorno, Proc. of the $1^{\text {st }}$ Conf. of Clot de Galvany studies, Elche, pp. 1-20, 2008.

[3] DCEE, Department of Control and Environmental Education Clot de Galvany, Annual Reports Management and Monthly Reports Management. Elche City Hall, Elche, 1998-2013.

[4] Decree 70/2009, Crea y regula el Catálogo Valenciano de Especies de Flora Amenazadas y se regulan medidas adicionales de conservación, Consell de la Generalitat, DOCV N. 6021, Valencia, pp. 20143-20162, 2009.

[5] SEBICOP \& TRAGSATEC, Lista Roja de la Flora Vascular Española, MAGRAMA, Madrid, pp 1-46, 2010.

[6] Royal Decree 139/2011, Desarrollo del Listado de Especies Silvestres en Régimen de Protección Especial y del Catálogo Español de Especies Amenazadas, MAGRAMA, BOE N.46, Madrid, pp. 20912-20951, 2011.

[7] Decree 32/2004, Catálogo Valenciano de Especies de Fauna Amenazadas, y se establecen categorías y normas para su protección, Consell de la Generalitat, DOCV N. 4705, Valencia, pp. 4963-4973, 2004.

[8] DITE, Department of Infrastructure, Territory and Environment, Resultados de la campaña de erradicación de galápagos exóticos, Report N.12, LIFE-Trachemys Project, LIFE09 NAT/E/0000529, Year 2012, Valencia, pp. 1-17, 2012.

[9] Aranda López, J.C \& Lacarte Monreal, M. E, Plan de Especial Protección del PNM Clot de Galvany, T.S. Planning and Management, Elche City Hall, Elche, pp. 1-25, 2013.

[10] EUROPARC-ESPAÑA, Anuario Europarc-España del estado de los espacios naturales protegidos 2005. Fernando González Bernáldez Foundation, Madrid, pp. 1-160, 2006.

[11] Pena, C., Presencia de Caulerpa racemosa en la Playa del Carabassí, Newsletter Clot de Galvany, N.9, Elche City Hall, Elche, pp. 6-7, 2007.

[12] Royal Decree 1628/2011, Regula el listado y Catálogo Español de Especies Exóticas Invasoras, MAGRAMA, BOE N. 298, Madrid, pp. 132711-132735, 2011. 
272 Sustainable Development, Vol. 1

[13] Royal Decree 630/2013, Regula el Catálogo Español de Especies Exóticas Invasoras. MAGRAMA, BOE N.185, Madrid, pp. 56764-56786, 2013.

[14] Decree 213/2009, Medidas para el control de especies exóticas invasoras en la Comunitat Valenciana, Consell de la Generalitat, DOCV N.6151, Valencia, pp. 42326-42332, 2009. 